
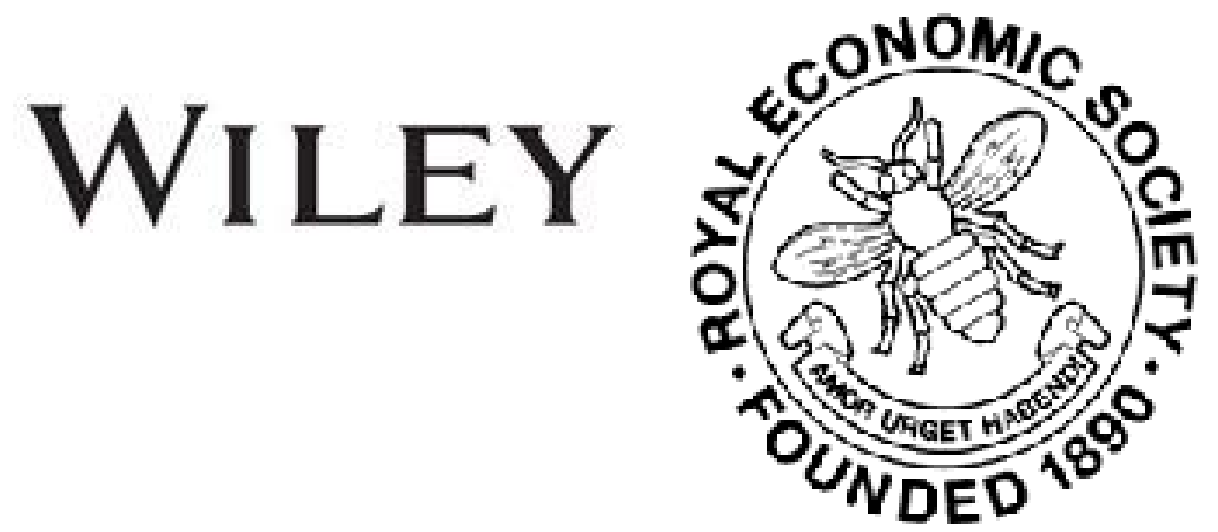

The Deviation of Exchanges

Author(s): E. C. Van Dorp

Source: The Economic Journal, Vol. 29, No. 116 (Dec., 1919), pp. 497-503

Published by: Wiley on behalf of the Royal Economic Society

Stable URL: http://www.jstor.org/stable/2223368

Accessed: 07-05-2016 17:34 UTC

Your use of the JSTOR archive indicates your acceptance of the Terms \& Conditions of Use, available at

http://about.jstor.org/terms

JSTOR is a not-for-profit service that helps scholars, researchers, and students discover, use, and build upon a wide range of content in a trusted digital archive. We use information technology and tools to increase productivity and facilitate new forms of scholarship. For more information about JSTOR, please contact support@jstor.org.

Wiley, Royal Economic Society are collaborating with JSTOR to digitize, preserve and extend access to The Economic Journal 


\section{The Deviation of Exchanges}

In Nos. 101 and 103 of this Journal Prof. Cassel has contended that the rates of exchange in a country are expressive of the internal value of the money, and for that reason are determined by the quotient of the inflation in that country; the inflation being proportional to the increase of the paper-money. In a contribution to No. 112 of this Journal, Prof. Cassel has amplified his view in this way, that a country which has an exportsurplus might see its money go $u p$ in value in foreign parts considerably above the rate which would correspond to the internal value of this money as expressed by its purchasing power.

This point is of great importance, as Prof. Cassel's latter thesis corresponds with the common view about the fall of the belligerents' exchanges, especially the German exchange in Holland, which is attributed to an import-surplus on the side of Germany.

The present article intends to show the fallacy of this view, and to elucidate the fall of the exchanges in a way which is different from both Prof. Cassel's former and his later article.

According to the current view, an import-surplus lowers the rates of exchange; on the other hand, borrowing abroad improves the rates of a country. Now, one or the other of these views must be wrong, as borrowing abroad (by obtaining foreign loans or private credits) and an import-surplus are both identical, being two aspects of the same fact.

Suppose this to be the normal balance of payments or claims of a country :

Imports, freights, interests ... 2,000 | Exports, gold exports ... $\ldots$ 2,000

Suppose this country increases its imports without increasing its exports, we may then get the following results :

\begin{tabular}{llll|lll} 
Imports, etc. $\ldots$ & $\ldots$ & $\ldots$ & 3,000 & $\begin{array}{l}\text { Exports, etc } \ldots \\
\begin{array}{l}\text { Borrowed abroad (foreign loans } \\
\text { and private credits) }\end{array}\end{array}$ & $\ldots$ & 1,000
\end{tabular}

The exact amount by which the imports, etc., exceed the exports, etc., must be borrowed abroad. This proves the fallacy of the statement that a foreign loan and an import-surplus have the opposite results.

(There is some lapse of time between the birth of a claim and its maturity. I do not enter into this detail as it is of no importance to the present investigation; it does not alter the fact that every import immediately gives rise to a claim; its only 
result being that the effect may be somewhat retarded; it does not change the matter in principle.)

The current contention is that the money of a country whose imports increase depreciates; that the exchange of this country falls. This is true, but there is some misunderstanding between this case and the former.

In pre-war times with a fixed parity, i.e. the relation between the value of the currency-units being constant, the rates of exchange can be described by the following diagram :

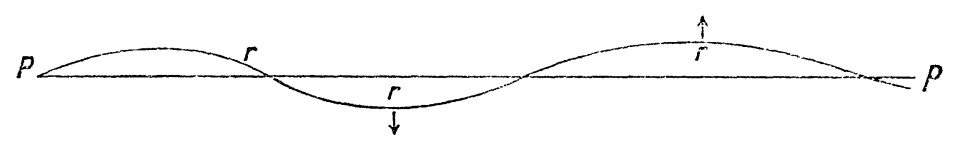

$P-p$ being the parity, $r$ being the rate.

The rate of exchange (the market value of the money) always tends towards the parity (the normal value of the money), fluctuates about it.

The cause of the fluctuation of the rate is the fluctuation of trade. With a given output, only a certain amount of export and import is possible; any import or export in excess of this amount will prove a loss, unless the rate changes. Yet in practice it is impossible to keep trade quite constant. Suppose the import obligations being the first to pass the norm, the surplus must then be paid by exports. The corresponding export-surplus, however, can only be brought about by a fall of exchange, because otherwise it would bring a loss; the importer will have to bear this loss. If, on the other hand, the export obligations are the first to pass the norm, the exporters will have to bear the loss, and the whole process will go the opposite way. As soon as in this way the balance between imports and exports has been restored on a lower level of exchanges, a reaction sets in, as imports will decrease in consequence of the low rate, and exchange will rise again.

This proves that exchange falls when imports expand beyond the normal amount, and must be paid by an increase of the exports beyond the normal amount; moreover, that this fall is only of a temporary nature, as it represents a deviation from the parity.

During the war we have witnessed big import-surpluses, which were not paid by exports, but met by foreign credits and loans, or sales of foreign shares, and we have also seen a permanent fall of some exchanges. This is obviously quite another case. In the former case there were no import surpluses, here there are.

An expansion of imports means quite another thing than an import-surplus, hence the misunderstanding. 
Expressing ourselves in terms of precision, we should say that the exchange of a country falls, not by the expansion of imports, but only at the moment at which this import is counterbalanced by a corresponding export, viz., by the counterbalancing-expansion of export.

Why then did exchanges fall if it could not be through these import-surpluses?

It must be kept in view that there is at present no fixed parity between the different currencies. Now, as the rate always tends towards the parity, it stands to reason that a constantly declining rate can only be caused by a declining parity.

According to the quantity theory, which in its main tendency is irrefutable, the value of a currency-unit not fixed to a standardmetal is chiefly determined by the extent of the circulation (including cheques and other money-saving instruments and methods) and the quantity of the consumption-stock.

It is obvious that both these agents have had a share in depreciating the belligerents' money, specially the German currency. The German circulation has swollen to a much greater extent than the Dutch one; the German production as well as the German stock have suffered to a much greater extent than the Dutch one; the exchange on Holland would have depreciated still more if Holland had not been obliged to keep a large stock of unproductive gold instead of productive capital or commodities. It may be useful to put the core of our argument in a second diagram.

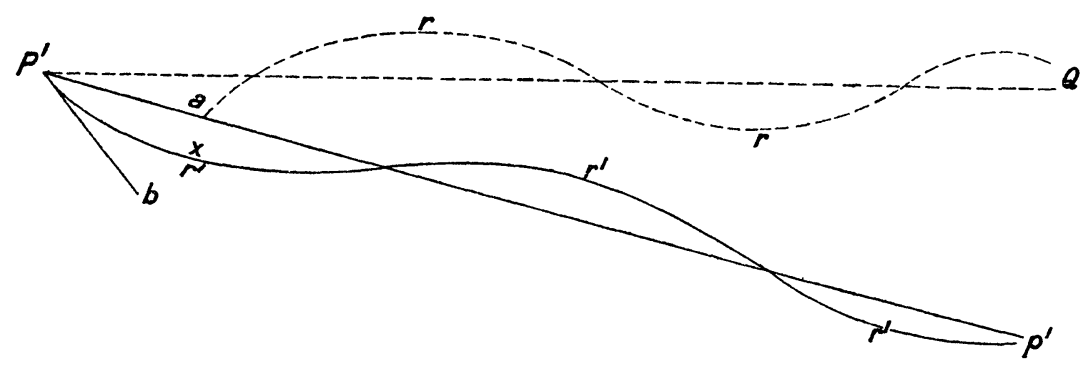

$P^{\prime}-p^{\prime}$ is the parity, $r^{\prime}$ are the rates. ( $P^{\prime} Q$ was the parity in pre-war times.)

The parity itself has fallen. The mistake made by the current explanation is, that the beginning of $P^{\prime}-p^{\prime}$, i.e. $P^{\prime}-a$, is taken for the beginning of a fluctuating rate $r$ on a parity $P^{\prime}-Q$. The fall of exchanges we have witnessed was not a fall below parity (i.e. a market rate below the normal rate), but a fallen parity (a fallen normal rate).

If we call to-day the German exchange "low," this expres- 
sion has only a historical meaning. It means that the parity between the two currencies is lower than it used to be; but whether it be low in the other sense, i.e. whether the rate be below parity, no one knows, as the parity is an invisible one-a purchasing power parity, as Prof. Cassel rightly calls it. This makes speculations in exchange very hazardous to-day. If the rate stands at $x$, the parity may lie, e.g. in $x$ itself, in $a$ or in $b$.

The depreciation of the German currency has acted on the exchange in the following way:

A depreciation of the currency means an advance in prices. As soon as this rise had reached the prices of export-commodities, the direct consequence must be a fall of exchange. What used to cost 100 marks in Germany now costs, say, 200 marks, yet there is no reason for an increased price in Holland, suppose the price there is the same as before, say, 59 guilders. For his bill of 59 guilders the exporter wants to get his 200 marks instead of 100 , and he can get them, as the importer can make 200 marks for what costs him 59 guilders in Holland. This process is seen by the bankers in the shape of an increased demand for Dutch exchange. Exporters hold back; importers will make haste until the new parity, 59 guilders $=200$ marks, is reached. The importsurpluses have nothing to do with it. As they became apparent at the same time as the fall of exchange, the conclusion was drawn that the latter was caused by the former. The actual occurrences were not subjected to close analysis, and, on the face of it, the explanation seemed to be satisfactory. The real connection was this, that both-the fall of exchange and the import-surpluses (brought about by means of credits, loans and sales of shares)were caused by the decline of the homestock.

By borrowing, the belligerents were enabled to restore their consumption-stock at the cost of their capital-stock. The foreign loan lays an interest-paying burden on the capital-stock. But for the time being the consumption-stock is increased, and this brings about the rise of exchange as it raises the value of the home money. The bankers' view that the rise is brought about by the demand of exchange only takes the external aspect of the matter in consideration. This also explains why the American exchange has fallen against Holland and has not risen against England. The United States have exported their consumption-stock by lending abroad and redeeming former loans, and so strengthened their capital-stock at the cost of their consumption-stock; the latter has diminished, from a relative point of view.

I agree with Prof. Cassel that the (par) rate of exchange is 
an expression of the money-value, and therefore determined by the quotient of the different inflations; but I disagree from him when he says that it must be proportional to the increase of the paper-money, and I do so for two reasons.

First, because the paper-money is only part of the currency of a country; secondly, because the increase of the currency is only one side of the inflation. The other side is the reduction of the consumption-stock. For example, suppose there was a money-circulation of 1,000. This circulation has doubled; according to Prof. Cassel, the inflation would be expressed by the number 2.

But Prof. Cassel has not taken into consideration that payments without money used to be effected to the amount of, say, 1,000, which has remained constant, and the consumption-stock has been reduced to, say, $\frac{1}{2}$ of what it was. Therefore, the inflation in reality will be expressed by the number $\left(\frac{3}{2} \times 2\right.$, or $) 3$.

In his last contribution Prof. Cassel has made a very valuable remark, which seems to refute my argument. Some rates have not been in correspondence with the internal value of the money as it was expressed by its purchasing power in the country. Prof. Cassel finds the explanation in the import-surpluses, and means to say that an export-surplus made the money-value of a country go up.

I have explained why I cannot accept this interpretation. In my opinion, an export surplus has the tendency of deteriorating the money of the country. I have to look for an explanation elsewhere. First, as Prof. Cassel himself grants, index numbers are never of sufficient accuracy to allow of the relative price-level being deduced therefrom with exactitude. But there is a second fact of far greater importance.

Price-level is only an average conception. Prices never move uniformly; by the same inflation, even in normal times, the pricelevel in two countries will never react exactly in the same way, yet it will react in approximately the same way. But the impediments to trade have brought about that we have to divide the price-level in each country in two sections : one section represents the prices of those cornmodities which are still an object of international trade, the other the prices of those goods which cannot be exported or imported. These latter prices move quite independently in every country. If we want to measure the fall of exchange by the index number, we can only use the prices of the former commodities. This may answer for the anomaly which Prof. Cassel observed. 
Some people have a not very clear notion that rates will rise again spontaneously in the same way as they have fallen. Others mean that this will happen when the import-surpluses are counterbalanced by export-surpluses, i.e. when all foreign credits and loans are refunded.

Our investigation leads to the result that exchange can only be restored by the reversal of the processes which have depreciated it : by a reduction of the circulation and a recovering of the productive power, and consequently of the consumption-stock, both to such an extent as to restore the former relations towards the money of those countries which did not experience a depreciation of their own money.

These are the only means beside gold exports of a certain nature.

Export-surpluses (i.e. refunding of loans) would act precisely in the wrong way, and must, not be effected before the capital-stock is strengthened.

Neither has the credit of the State anything to do with the rates of exchange, nor can any artificial expedients be of any avail. Speculation and psychological agents can only answer for temporary fluctuations. On the other hand, gold taken from the gold-reserves will improve the rate. The gold-reserves may be compared to a treasure hidden in the soil. It is inactive in every way so long as it is hidden; but as soon as it is exported its value is added to the stock of commodities by the corresponding import. The export of gold, which has first to be produced, however, plays the same part with regard to rates as any other export commodity. It would be of no use to strain this production beyond its natural limits with a view of improving rates; on the other hand, it would only be logical to raise the price of gold in accordance with the fall of the sovereign.

The argument also tends to show the fallacy of the view that the present low exchange involves an export premium. An exchange below parity involves an export-premium, but it is immaterial to trade whether the parity between German and Dutch money is 60 or 25 cts. If a guilder fetches four marks instead of one and a half, this is not a gain of two marks and a half for the man who possesses the guilder, but four marks now fetch as many commodities as formerly one mark and a half. Yet the wrong view is held by many, and forms a dangerous weapon in the hands of protectionists.

To resume the main argument :

The present fall of exchanges involves a fall of the parity, 
and is brought about by the extension of the currency and the reduction of production.

The import-surpluses are brought about by foreign loans, etc., and temporarily improve exchanges.

The way to restore exchanges will be to reduce circulation and recover production, and eventually to export the gold from the reserve.

\section{E. C. VAN DoRP}

\section{Offictal Papers.}

Royal Commission on Agriculture. Minutes of Evidence, Vols. I., II. and III, 5th August to 24th September, 1919.

An enquiry into the economic prospects of the agricultural industry in Great Britain. Prices, cost of production, wages and hours of labour.

Royal Commission on the Income Tax. Second, third and fourth instalments of Minutes of Evidence with Appendices. 2s., 3s. and $3 s$. $6 d$.

Summary Statement of the Legislative Provisions for the Prevention of Dumping in . . . Canada, . . . Australia, . . . South Africa and the United States [Cd. 265.]

Coal Industry Commission Reports and Minutes of Evidence on the First Stage of the Inquiry. [Cd. 359.] 3s. 6d.

. . On the Second Stage. [Cd. 360.] 7s.

Ministry of Labour: Minutes of Evidence Taken before the Committee of Inquiry into the Scheme of Out-of-work Donation. [Cd. 407.]

Report of Select Committee on High Prices and Profits. [H.C. 166.] $5 \frac{1}{2} d$.

Prices and Wages in India. Calcutta, Department of Statistics. $3 s$.

Index Numbers of Indian Prices, 1861-1918. Calcutta, Department of Statistics. 1s. $3 d$.

No. 116 -vol. XXIX. 